\title{
Neurotoxocariasis associated with lower motor neuron disease. Report of one case
}

\author{
JOSEF FINSTERER, MD, PhD ${ }^{1}$, VERENA KALLAB, $\mathrm{MD}^{2}$, \\ HERBERT AUER, MD ${ }^{3}$
}

\begin{abstract}
We report a 51-year-old male with a history of palpitations, hepatopathy and hypercholesterolemia, who habitually ate raw goat meat, and developed general fasciculations, muscle cramps in the lower limbs, distal muscle weakness and wasting, without upper motor neuron signs or sensory abnormalities. Diagnostic work-up revealed positive antibodies against Toxocara canis in the serum and cerebrospinal fluid. Nerve conduction studies revealed a proximal and distal axonal lesion of motor nerves and needle electromyography was indicative of acute and chronic denervation with giant motor unit action potentials. Despite a therapy with albendazole and riluzole, muscle weakness and wasting further progressed and affected also the respiratory muscles. Follow-up nerve conduction studies and electromyography confirmed progression of the axonal degeneration. Whether lower motor neuron disease was causally related to neurotoxocariasis or due to a general metabolic defect, remains speculative.

(Rev Med Chile 2010; 138: 483-486).
\end{abstract}

Key words: Electromyography; Motor neuron disease; Neuromuscular diseases; Toxocariasis.

\section{Neurotoxocariasis asociada a enfermedad de motoneurona inferior. Presentación de un caso}

Presentamos un hombre de 51 años con una historia de palpitaciones, hepatopatía e hipercolesterolemia que comía habitualmente carne de cabra cruda, que desarrolló un cuadro caracterizado por fasciculaciones generalizadas, calambres musculares en las extremidades inferiores, pérdida de fuerza y atrofia muscular distal, sin signos de lesión de motoneurona superior o alteraciones sensitivas. El laboratorio mostró anticuerpos anti Toxocara canis en suero y líquido cefalorraquídeo. La electromiografía mostró una lesión axonal proximal y distal de nervios motores y denervación con potenciales de acción gigantes en las unidades motoras. A pesar de tratarse con albendazol y riluzona, la debilidad muscular y atrofia continuaron progresando. Una nueva electromiografía confirmó la progresión de la degeneración axonal. La asociación entre esta enfermedad de motoneurona inferior y la neurotoxocariasis, es especulativa.
${ }^{1}$ Neurological Department, Krankenanstalt Rudolfstiftung, Vienna.

${ }^{2}$ Abt. f. Infektionskrankheiten, Kaiser Franz Josef Spital, Vienna.

${ }^{3}$ Dpt. of Medical Parasitology, Institute for Specific Prophylaxis and Tropical Medicine, Medical University of Vienna. Vienna, Austria.

Recibido el 26 de Agosto de 2009, aceptado el 19 de Marzo de 2010.

Correspondencia a: Josef Finsterer, MD, PhD Postfach 20

1180 Vienna Austria, Europe. Tel. +43-1-71165-92085 E-mail: fifigs1@yahoo.de 
I nfection with Toxocara canis (T. canis) occasionally manifests in the central-nervoussystem (CNS) and peripheral-nervous-system $(\mathrm{PNS})^{1}$. One of these CNS or PNS-manifestations is myelitis and radiculitis ${ }^{1-14}$. Here we report a patient with previous neurotoxocariasis who clinically and electromyographically developed lower motor-neuron-disease (LMND).

\section{Case report}

The patient is a 51 yo-male with a history of hepatitis-A in childhood with increase in liver enzymes presumably since then, depression and anxiety for which he received carbamazepine for $15 \mathrm{y}$ until age $49 \mathrm{y}$, hyperlipidemia since several years, pollakisuria, benzodiazepine misuse, palpitations since age $50 \mathrm{y}$, and a positive family history for hepatopathy (father, two sisters) and arterial hypertension (mother). He had developed general fasciculations since twelve months, muscle cramps in the lower limbs (LL) since six months, weakness of the distal upper limb (UL) muscles since five months, and weakness in the LL when climbing stairs since age $50 \mathrm{y}$. He occasionally reported transient double vision and palpitations.

Neurologic investigations revealed sore neckmuscles, weakness for right elbow-extension (M5-), finger straddling bilaterally (M5-), and foot-extension bilaterally (M4-), reduced respectively absent tendon-reflexes, fasciculations in the intrinsic hand muscles, UL distal wasting, and hypotonia. All sensory modalities were intact. Creatine-kinase was repeatedly elevated with a maximal value of 529U/l (n, $<170 \mathrm{U} / \mathrm{l})$ but resting lactate was normal. Repeatedly elevated were also the transaminases and the gamma-glutamyl transpeptidase. Nerve-conduction-studies showed reduced CMAP-amplitude upon stimulation of the right and left median, the right and left ulnar, and the left tibial nerve(s) and reduced nerveconduction-velocity on the right median, left ulnar, right and left peroneal, and left tibial nerve(s). F-waves were absent upon retrograde stimulation of the right ulnar nerve. Nerve conduction studies of sensory nerves showed normal conduction velocities of the right median, left median, left ulnar and left sural nerves. Needle electromyography of two muscles revealed extensive fibrillations and fasciculations, prolonged mean MUAP-duration, increased polyphasicity, and reduced interferencepattern with increased amplitude. Cerebrospinal fluid (CSF)-investigations revealed a protein of 53 $\mathrm{mg} / \mathrm{dl}$ (n, 18-43 mg/dl) and elevated lactate. T. $c a-$ nis antibodies were positive in the serum and CSF (40 AKE). Westernblot for IgG-antibodies against T. canis was positive in the CSF. Creatine-kinase, glutamate-oxalate-transaminase, glutamatepyruvate-transaminase, and gamma-glutamyltranspeptidase were moderately elevated. Resting serum lactate and lead were normal. Investigations for worm eggs in the stool were negative. Cardiac examination revealed paroxysmal atrial fibrillation and a small pericardial effusion.

Therapies with albendazole $(400 \mathrm{mg} / \mathrm{d})$ during three weeks and with diethyl-carbazine were ineffective and T. canis antibodies remained elevated in the serum and CSF. Weakness slowly but continuously progressed and resulted in gait-disturbance, repeated falls, and wheel-chair boundness. Six months after the first visit nerveconduction-velocity of the left sural nerve was reduced. Needle-electromyography of the right tibial and right common extensor digitorum muscles showed signs of acute and chronic denervation. Lung-function parameters and bulbar functions were normal. During the following months weakness also involved the respiratory muscles resulting in respiratory insufficiency, emergency intubation, and long-term mechanical ventilation upon the patient's explicit request.

\section{Discussion}

The patient reported is interesting for the association of neurotoxocariasis and the subsequent development of LMND. Whether there was a causal relation between neurotoxocariasis and LMND remains speculative. Either the patient developed LMND as a consequence of the infection with T. canis or neurotoxocariasis and LMND were causally unrelated and occurred coincidentally in a time-related manner. Arguments for a causal relation are that myelitis and polyradiculitis have been reported as manifestations of an infection with $T$. canis $^{2-14}$, that there are human and animal studies indicating that larvae of T. canis also migrate to the spinal $\operatorname{cord}^{9,15}$, that antibodies against $T$. canis persisted in the CSF during clinical deterioration, and that neurotoxocariasis and 
Table 1. Nerve conduction studies in the patient reported

\begin{tabular}{|c|c|c|c|}
\hline Investigated nerve & DI & NCV (m/s) & NAP (mV) \\
\hline Right median (motor) & 4.9 & 37.6 & 4.2 \\
\hline Left median (motor) & 7.5 & 52.4 & 0.4 \\
\hline Right ulnar (motor) & 4.2 & 51.3 & 5.2 \\
\hline Left ulnar (motor) & 6.0 & 33.3 & 1.3 \\
\hline Right peroneal (motor) & 6.2 & 3.81 & 4.3 \\
\hline Left peroneal nerve (motor) & 5.1 & 40.0 & 2.9 \\
\hline Left tibial (motor) & 4.3 & 40.6 & 5.2 \\
\hline Right median (sensory) & 2.6 & 56.9 & 9.2 \\
\hline Left median (sensory) & 3.1 & 50.0 & 4.8 \\
\hline Left ulnar (sensory) & 2.6 & 49.3 & 11.0 \\
\hline Left sural & 2.2 & 41.3 & 12.0 \\
\hline
\end{tabular}

DI: distal latency, NCV: nerve conduction velocity, NAP: nerve action potential.

LMND were time-related. Arguments against a causal relation are that serial MRIs did not show swelling, enhancing structures, or granuloma in the spinal cord or surrounding meningeas, that the patient did not develop upper motor neuron signs, as has been previously reported ${ }^{10}$; that there was no eosinophilia, neither in the serum nor CSF, although acute myelitis could have passed already and LMND and antibodies against T. canis in the CSF may have been the only remains of the disease, and that albendazole did not resolve the clinical manifestations.

Clinical manifestations of myelitis from an infection with $T$. canis may include motor and sensory abnormalities (paresthesia, hypesthesia, positive Lhermitte-sign $)^{10}$. Blood investigations may show leukocytosis, eosinophilia, or antibodies against $T$. canis $^{9-11}$. CSF-investigations may reveal pleocytosis with a high percentage of eosinophils, elevated protein, increased IgG-synthesis, and T. canis antibodies $^{9-11}$. On MRI myelitis usually manifests as swelling of the spinal cord with or without enhancement but without compression ${ }^{10,12,13}$ Additionally, there may be T2-hyperintensities, preferentially in the posterior and lateral columns $5^{5,10,13}$. Myelitis and radiculitis may go along with or without cerebral manifestations, such as enhancing cortical or subcortical lesions ${ }^{11}$, and may respond to albendazole, mebendazole, thiobendazole, diethyl-carbazine, or corticosteroids but may nonetheless reccur ${ }^{5,9,13}$.
To explain a possible causal relation between neurotoxocarosis and LMND in the patient reported, three pathogenetic scenarios can be put forward: First, larvae of T. canis on their migration from the intestines to target tissues carry with them bacteria, viruses, or other infectious agents ${ }^{16-18}$. Via this pathway some patients may have been infected with the polio-virus or other agents. In a study on 191 patients with poliomyelitis $13,6 \%$ were positive for antibodies against T. canis $^{18}$ Second, it is well known that larvae in humans do not usually mature after their migration but die and become a focus of granulomatous tissue-reaction around their disintegrating bodies ${ }^{18}$. Such a mechanism is assumed to cause epilepsy. Accordingly, patients with epilepsy are four times more frequently positive for antibodies against $T$. canis than controls ${ }^{18}$. Similarly, larvae may cause a focal granulomatous reaction when they reach the spinal cord, compromising anterior horn cells. Third, LMND may be due to allergenic or immune mechanisms of undetermined significance since myelitis frequently recurs despite adequate treatment ${ }^{11}$.

The clinical manifestations of our patient could be also explained by the presence of a mitochondrial disorder assumed upon transient double vision, tinnitus, paroxysmal atrial fibrillation, progressive weakness and wasting, mimicking $\mathrm{LMND}^{19,20}$, elevated CK and transaminases, increased CSF-lactate, hepatopathy and the positive family history for it, affection of the sensory 
nerves, and hyper-cholesterolemia. Possibly, the infection caused oxidative stress, such that a preexisting mtDNA mutation with low heteroplasmy rate became pathogenic by exceeding a critical threshold level.

Neurotoxocariasis may be associated with LMND although it remains speculative if the relation was causal or coincidental. Patients with LMND should be screened for antibodies against T. canis and vice versa LMND should be excluded in patients with neurotoxocariasis.

\section{References}

1. Finsterer J, Auer H. Neurotoxocarosis. Rev Inst Med Trop Sao Paulo 2007; 49: 279-87.

2. Dauriac-Le Masson V, Chochon F, Demeret S, PierrotDeseilligny C. Toxocara canis meningomyelitis. J Neurol 2005; 252: 1267-8.

3. Eberhardt O, Bialek R, Nägele T, Dichgans J. Eosinophilic meningomyelitis in toxocariasis: case report and review of the literature. Clin Neurol Neurosurg 2005; 107: 432-8.

4. Engel H, Spieckermann DA, Tismer R, Möbius W. Acute meningomyelitis due to Toxocara larvae. Dtsch Med Wochenschr 1971; 96: 1498.

5. Goffette S, Jeanjean AP, Duprez TP, Bigaignon G, Sindic CJ. Eosinophilic pleocytosis and myelitis related to Toxocara canis infection. Eur J Neurol 2000; 7: 703-6.

6. Ishihara T, Ozawa T, Nemoto M, Shinbo J, Igarashi S, Tanaka K, Nishizawa M. Toxocara canis myelitis. Nippon Naika Gakkai Zasshi 2007; 96: 141-3.

7. Kira J. Parasitic myelitis. Nippon Naika Gakkai Zasshi 2006; 95: 1255-9.

8. Mitsuhashi Y, Naitou K, Yamauchi S, Naruse H, Matsuoka Y, Nakamura-Uchiyama F, et al. A case of the myelitis due to Toxocara canis infection complicated with cervical spondylosis. No Shinkei Geka 2006; 34: 1149-54.

9. Moreira-Silva SF, Rodrigues MG, Pimenta JL, Gomes CP, Freire LH, Pereira FE. Toxocariasis of the central nervous system: with report of two cases. Rev Soc Bras Med Trop 2004; 37: 169-74.

10. Osoegawa M. Diagnosis and treatment of CNS parasite infection with special reference to parasitic myelitis. Rinsho Shinkeigaku 2004; 44: 961-4.

11. Ota S, Komiyama A, Johkura K, Hasegawa O, Kondo K. Eosinophilic meningo-encephalo-myelitis due to Toxocara canis. Rinsho Shinkeigaku 1994; 34: 1148-52.

12. Sellal F, Picard F, Mutschler V, Marescaux C, Collard M, Magnaval JF. Myelitis caused by toxocara canis (larva migrans). Rev Neurol (Paris) 1992; 148: 53-5.

13. Umehara F, Ookatsu H, Hayashi D, Uchida A, Douchi Y, Kawabata H, e al. MRI studies of spinal visceral larva migrans syndrome. J Neurol Sci 2006; 249: 7-12.

14. Wang C, Huang CY, Chan PH, Preston P, Chau PY. Transverse myelitis associated with larva migrans: finding of larva in cerebrospinal fluid. Lancet 1983; 1: 423.

15. Woodruff AW. Helminths as vehicles and synergists of microbial infections. Trans R Soc Trop Med Hyg 1968; 62: 446-52.

16. Khalil HM, Khattab AK, el-Fattah SM, Khalid ML, Awaad S, Rifaat MA. Interrelationship between poliomyelitis and Toxocara infection. Trans $\mathrm{R}$ Soc Trop Med Hyg 1971; 65: 599-601.

17. NN. Poliomyelitis and Toxocara infection. Lancet 1972; 1: 27.

18. Woodruff AW, Bisseru B, Bowe JC. Infection with animal helminths as a factor in causing poliomyelitis and epilepsy. BMJ 1966; 1: 1576-9.

19. Finsterer J. Mitochondriopathy mimicking amyotrophic lateral sclerosis. Neurologist 2003; 9: 45-8.

20. Finsterer J. Mitochondriopathy as a differential diagnosis of amyotrophic lateral sclerosis. Amyotroph Lateral Scler Other Motor Neuron Disord 2002; 3: 219-24. 